\title{
Differences in Efficiency of Innovation Performance among Middle-income Countries: An Empirical Approach
}

Fatma ÜNLÜ ${ }^{1}$

\begin{abstract}
The purpose of this paper is to determine empirically the differences in the efficiency of innovation performance among middle-income countries. To achieve this aim, it was used cluster analysis which is one of the multivariate statistical techniques. Ward's agglomerative hierarchical method was employed for cluster analysis. For determining the efficiency of innovation performance, it was followed process suggested by Kula and Ünlü (2019). So, cluster analysis was performed separately for inputs and outputs indicators. Secondly, discriminant analysis was used to identify factors that lead to differences in efficiency. According to the World Bank's income classification, it was included a total of 54 countries, including 23 lower-middle-income and 31 upper-middle-income. The data used in the analysis were obtained from the Global Innovation Index. The findings confirm the existence of the inefficiency problem in terms of innovation performance in middleincome countries.
\end{abstract}

Keywords: Innovation, middle-income countries, cluster analysis, discriminant analysis. Jel Codes: O30, O57, C38, C39.

\section{Orta Gelirli Ülkelerde İnovasyon Performansının Etkinliğindeki Farklılıklar: Ampirik Bir Yaklaşım}

ÖZ: Bu çalışmanın amacl, orta gelirli ülkelerde inovasyon performansının etkinliğindeki farklılıklarl ampirik olarak tespit etmektir. Bu amaca ulaşmak için, çok değişkenli istatistiksel tekniklerden kümeleme analizi kullanılmıştır. Bu analiz için Ward'ın aglomeratif hiyerarşik yöntemi kullanılmıştır. İnovasyon performansının etkinliğini belirlerken, Kula ve Ünlü (2019) tarafindan önerilen süreç takip edilmiştir. Böylece girdi ve çıktı göstergeleri için analizler ayrı ayrı yapılmıştır. İkinci olarak, etkinlikte farklılıklara yol açan faktörleri belirlemek için diskriminant analizi kullanılmıştır. Dünya Bankası'nın gelir sinıflandırmasına göre, 23 alt-orta gelirli ve 31 üst-orta gelirli ülke olmak üzere toplam 54 ülke analize dahil edilmiştir. Analizde kullanilan veriler Global İnovasyon Endeksi'nden elde edilmiştir. Bulgular orta gelirli ülkelerde inovasyon performansı açısından etkinlik sorununun varlığını doğrulamaktadır.

Anahtar Kelimeler: İnovasyon, orta gelirli ülkeler, kümeleme analizi, diskriminant analizi. Jel Kodları: O30, O57, C38, C39.

\footnotetext{
${ }^{1}$ Dr. Öğr. Üyesi, Erciyes Üniversitesi, İktisadi ve İdari Bilimler Fakültesi, İktisat Bölümü, funlu@erciyes.edu.tr, orcid.org/0000-0003-1822-9965.
} 


\section{Introduction}

Recently, it is seen that innovation is the most important factor in achieving economic growth, increasing social welfare, and obtaining an advantage in global competitiveness. The concept of innovation was first described by economist Joseph Schumpeter (1934) as the driving force of development. According to Schumpeter, innovation is the introduction into the market of a new feature of the existing product or a product that consumers do not yet know, putting the new production method into practice, entering the new market, finding new sources of supply and having an industry's new organization (Schumpeter, 1934: 66).

There are many definitions of the innovation in the literature, but it has been usually used the definition of innovation in the Oslo Manual published by OECD-Eurostat (2005). According to Oslo Manual, innovation is defined as "the implementation of a new or significantly improved product (good or service), or process, a new marketing method, or a new organizational method in business practices, workplace organization or external relations" (OECD-Eurostat, 2005: 50). Like the definition of innovation, there have been also different aspects of the innovation classification in the literature. For example, Henderson and Clark (1990) made a different classification by expressing that innovation is structural innovation, which is similar to radical and gradual innovations but in the middle of these two types of innovation. Christensen (2010) examined innovation in two groups as supporting innovations and destructive innovations. According to Trott (2005), innovation types are classified as the product, process, organizational, production, marketing and service innovations. Some authors agree that there are two types of innovation: technological innovations (product and process innovations) and non-technological innovations (marketing and organization innovations) (Schmidt and Rammer, 2007: 2). According to the Oslo Manual, the types of innovation are divided into four groups: product, process, marketing, and organizational innovation.

Porter (1991) in his book entitled Competitiveness of Nations claimed that productivity increases raised the competitiveness level and competitiveness contributed to social welfare. In other words, competitiveness should be increased in order to increase the standard of living and welfare in a country. Competitiveness also can be achieved through productivity increases. The main tool for increasing productivity is seen as innovation. In other words, due to innovation it will be possible to transform the country's resources into useful products and services for the society and to create economic value from these products and services. He stated that sustainable productivity increases depend on an economy that continually improves itself. That's why innovation is important especially developed countries. So these countries called middle-income countries have been stuck in the same income group for many years which is called the middle-income trap. These countries which cannot compete with developed countries in innovative products requiring high skill level and low-income countries in labor-intensive products fall into the middle-income trap. It is possible for these countries to reach an upper 
income level by shifting their production structures to technological processes (Gill and Kharas, 2007; Yeldan, 2012; Jankowska, 2012; Egawa, 2013). So, the middleincome countries need to increase their productivity through innovation.

Due to the problems mentioned above, the aim of this study is to determine empirically the differences in the efficiency of innovation performance in middleincome countries. To achieve this aim, it was used cluster analysis which is one of the multivariate statistical techniques. Ward's agglomerative hierarchical method was employed for cluster analysis. In determining the efficiency of innovation performance, it was followed process suggested by Kula and Ünlü (2019). So, firstly cluster analysis was performed separately for inputs and outputs indicators. Secondly, discriminant analysis was used to identify factors that lead to differences in efficiency. Similar to the previous analysis, it was performed separately.

The data included in the analysis have obtained from The Global Innovation Index2018. The study is organized as follows. After the introduction section, the second section contains the literature review. The next section explains the methodology and data used in the empirical analysis. The fourth section includes empirical results and the last section contains the conclusion and policy recommendations.

\section{Literature Review}

There are many studies that aim to evaluate the concept of innovation from different aspects and different levels such as firm, sector or country. In these studies, econometric, statistical etc. methods are used generally. One of the most used multivariate statistical methods is clustering analysis. This analysis is used in the literature to measure the performance of the countries of firms from different aspects (For example, Artis and Zhang, 2002; Altınel, 2012; Strozek, 2012; Baculakova and Gress, 2015; Popescu et al., 2016; Bivand et al., 2017; Ar1 and Y1ldiz, 2018). Also, there are many studies to measure the innovation performance of the countries or country groups by using cluster analysis. For example, Yeloğlu (2009) investigated the knowledge economy performance of OECD countries using cluster analysis. The results obtained from the analysis showed that Turkey is similar to Northern Europe countries in terms of the knowledge economy performance. Similarly, Erkekoğlu and Arıç (2013) analyze APEC countries and Turkey using the same method in terms of the indicators of information society. The authors reached the result that APEC consists of countries which have different level indicators of information society.

Özbek and Atik (2013) determined the place of Turkey among the EU countries in terms of the innovation indicators using the data in the European Innovation Scoreboard. It was used cluster analysis in the study. The results indicated that Turkey takes place in the same group with Romania and Bulgaria and it has a similar innovation performance. Accordingly, Ersöz (2009) aimed to determine the place of Turkey among the selected countries (for example, EU, USA, Japan etc.) in terms of the innovation indicators using the data in the European Innovation 
Scoreboard. The results obtained from these studies reached that Turkey takes place in the same group with Eastern Europe countries. Saatçioğlu and Bildirici (2017) also aimed to determine the place of Turkey between OECD countries in terms of innovation indicators and to identify the similarities and differences of innovation among OECD countries by using cluster analysis. They reached the result that Turkey's performance in this field is below the OECD average.

In the literature, there is a limited number of studies measuring the efficiency of innovation performance. These studies generally focus on data enveloped analysis (DEA) as a method (Nasierowski and Arcelus, 2012). For example, Çiçek and Onat (2012) used DEA to measure the effect of innovation activities on firm performance. The results showed that $R \& D$ expenditures have a positive effect on firm performance. Similarly, Cai (2011) calculated efficiency scores by DEA for a total of 22 countries including BRICS and G-7 countries. The results of the analysis showed that BRICS countries differ from each other in terms of the efficiency of national innovation system. They claimed that "to avoid the called middle-income trap, the BRICS should transform their factor-driven growth patterns into innovation-driven growth patterns". Herimalala and Gaussens (2012) also used DEA model in order to measure the efficiency of innovation processes in small and medium-sized enterprises in France. The results displayed that it is available that $\mathrm{x}-$ inefficiency in the innovation processes of SMEs. Broekel et al. (2013) examined the innovation efficiency of German regions by using a robust shared-input DEA model in two periods: 1999-2003 and 2004-2008. They found that there are differences in regional innovation efficiencies among German regions. So, it was confirmed that the existence of a difference in innovation efficiency between East and West German regions.

In the literature, one of the commonly used methods for measuring innovation performance is factor analysis. For example, Y1lmaz et al. (2016) determined the competitiveness of the provinces on the level 26 NUTS spatial units in Turkey. They calculated the innovation index using factor analysis. Similarly, RoszkoWojtowicz and Bialek (2017) aimed to measure the innovative potential of EU countries by using factor analysis. Apart from DEA, factor and cluster analysis are used to measure innovation performance. For example, Foreman-Peck (2012) and Chou and Gao (2013) respectively used probit and tobit regression analyses. On the other hand, Hajek and Henriques (2017) used artificial neural networks model (ANN) to investigate both intra and inter regional determinants of innovation performance. The data used in the analysis were obtained from the $4^{\text {th }}$ and $5^{\text {th }}$ Community Innovation Surveys of NUTS2 regions. According to the results, they suggested that specific strategies should be developed for each region. Finally, Barasa et al. (2019) investigated the technical efficiency effect arising from innovation inputs (internal R\&D, human capital, etc.) in firms in Sub-Saharan Africa. In the study, a heteroscedastic half-normal stochastic frontier was used for analyzing. As a result, it was found that internal $R \& D$ and foreign technology have negative effects on technical efficiency. 
When examined related literature, it was determined that different methods were used for different country and country groups. As can be seen, clustering analysis is often used to measure innovation performance. But no study has been found measuring the efficiency of innovation in middle-income countries using cluster analysis. The motivation of this paper lies in these points. Additionally, it also refers to the original contribution of the study.

\section{Data and Method}

A total of 21 indicators in the Global Innovation Index were used to determine the efficiency of the middle-income countries in their innovation performance. The Global Innovation Index, which has published since 2007 is developed to measure the innovation performance of the countries. This index is a composite index developed by the INSEAD. Additionally, it aims to capture the different aspects of innovation by applying 21 indicators grouped into seven thematic areas: institutions, human capital and research, infrastructure, market sophistication, business sophistication, knowledge and technology outputs, and creative outputs. In this index, institutions, human capital and research, infrastructure, market sophistication, and business sophistication are called innovation inputs, while knowledge and technology outputs and creative outputs are called innovation outputs. The indicators used the analysis can be seen in Table 1 .

Table 1: The indicators included the analysis

\begin{tabular}{ll}
\hline Basic Indicators & Sub-indicators \\
\hline Institutions & $\begin{array}{l}\text { Political environment, regulatory environment and } \\
\text { business environment }\end{array}$ \\
Human capital and research & $\begin{array}{l}\text { Education, tertiary education, R\&D } \\
\text { Infrastructure }\end{array}$ \\
Market sophistication & $\begin{array}{l}\text { Credit, investment, trade, competition \& market scale } \\
\text { Business sophistication }\end{array}$ \\
Knowledge and technology & $\begin{array}{l}\text { absorption } \\
\text { Knowledge creation, knowledge impact, knowledge } \\
\text { diffusion }\end{array}$ \\
Creative outputs & $\begin{array}{l}\text { Intangible assets, creative goods and services, online } \\
\text { creativity }\end{array}$ \\
\hline
\end{tabular}

The World Bank classifies the world's economies into four income groups as high, upper-middle, lower-middle, and low. Considering GNI per capita calculated using the Atlas Method, the countries are ranked according to their income thresholds (See, Table 2). 
Table 2: Thresholds for classification by income

\begin{tabular}{ll}
\hline \multicolumn{1}{c}{ Threshold } & \multicolumn{1}{c}{ GNI/Capita (current US\$) } \\
\hline Low-income & $<995$ \\
Lower-middle-income & $996-3,895$ \\
Upper-middle-income & $3,896-12,055$ \\
High-income & $>12,055$ \\
\hline
\end{tabular}

Source: The World Bank.

Considering the World Bank's income classification, we included the middleincome countries which consist of the lower-middle-income countries and the upper-middle-income countries. So, a total of 54 countries, including 23 lower middle-income and 31 upper middle-income, were included in the analysis (See Table 3).

Table 3: The list of countries included in this analysis

\begin{tabular}{ll}
\hline $\begin{array}{l}\text { Middle-income } \\
\text { Groups }\end{array}$ & Countries \\
\hline $\begin{array}{l}\text { Lower Middle-income } \\
\text { Countries } \\
\text { (23 countries) }\end{array}$ & $\begin{array}{l}\text { Bangladesh, Cambodia, Cameroon, Co'te d'Ivoire, Egypt, El } \\
\text { Salvador, Georgia, Ghana, Honduras, India, Indonesia, Kenya, } \\
\text { Kyrgyzstan, Moldova, Morocco, Nigeria, Pakistan, Philippines, Sri } \\
\text { Lanka, Tunisia, Ukraine, Vietnam, Zambia. }\end{array}$ \\
& $\begin{array}{l}\text { Albania, Algeria, Armenia, Azerbaijan, Belarus, Brazil, Bulgaria, } \\
\text { China, Colombia, Costa Rica, Dominican Republic, Ecuador, }\end{array}$ \\
$\begin{array}{l}\text { Countries } \\
\text { (31 countries) }\end{array}$ & $\begin{array}{l}\text { Guatemala, Iran, Jamaica, Jordan, Kazakhstan, Lebanon, Malaysia, } \\
\text { Mauritius, Mexico, Namibia, Paraguay, Peru, Romania, Russian }\end{array}$ \\
& Federation, Serbia, South Africa, Macedonia, Thailand, Turkey. \\
\hline
\end{tabular}

The Global Innovation Index contains two sub-indexes as innovation input subindex and innovation output sub-index. Figure 1 and Figure 2 show the sub-index values of inputs and outputs for lower and upper middle-income countries, respectively.

Figure 1 indicates innovation input and output sub-indexes of lower middle-income countries. By figure, while the country with the highest performance in terms of innovation input sub-index is Georgia (44.44); the country with the lowest performance is Zambia (28.55). India (42.53), Vietnam (42.17), Ukraine (40.45) and Tunisia (40.25) can be considered as high performance countries. On the other hand, Co'te d'Ivoire (28.60), Pakistan (29.05) and Nigeria (29.85) also are the countries that have low performance according to the innovation inputs. In terms of innovation output sub-index, it can be seen that the countries with high performance are Ukraine (36.59), Moldova (35.41) and Vietnam (33.70) respectively. The countries with the worst performance are Co'te d'Ivoire (11.32), Zambia (12.77) and Nigeria (14.89). 
Figure 1: Innovation Input and Output Sub-Indexes of Lower Middle-Income Countries

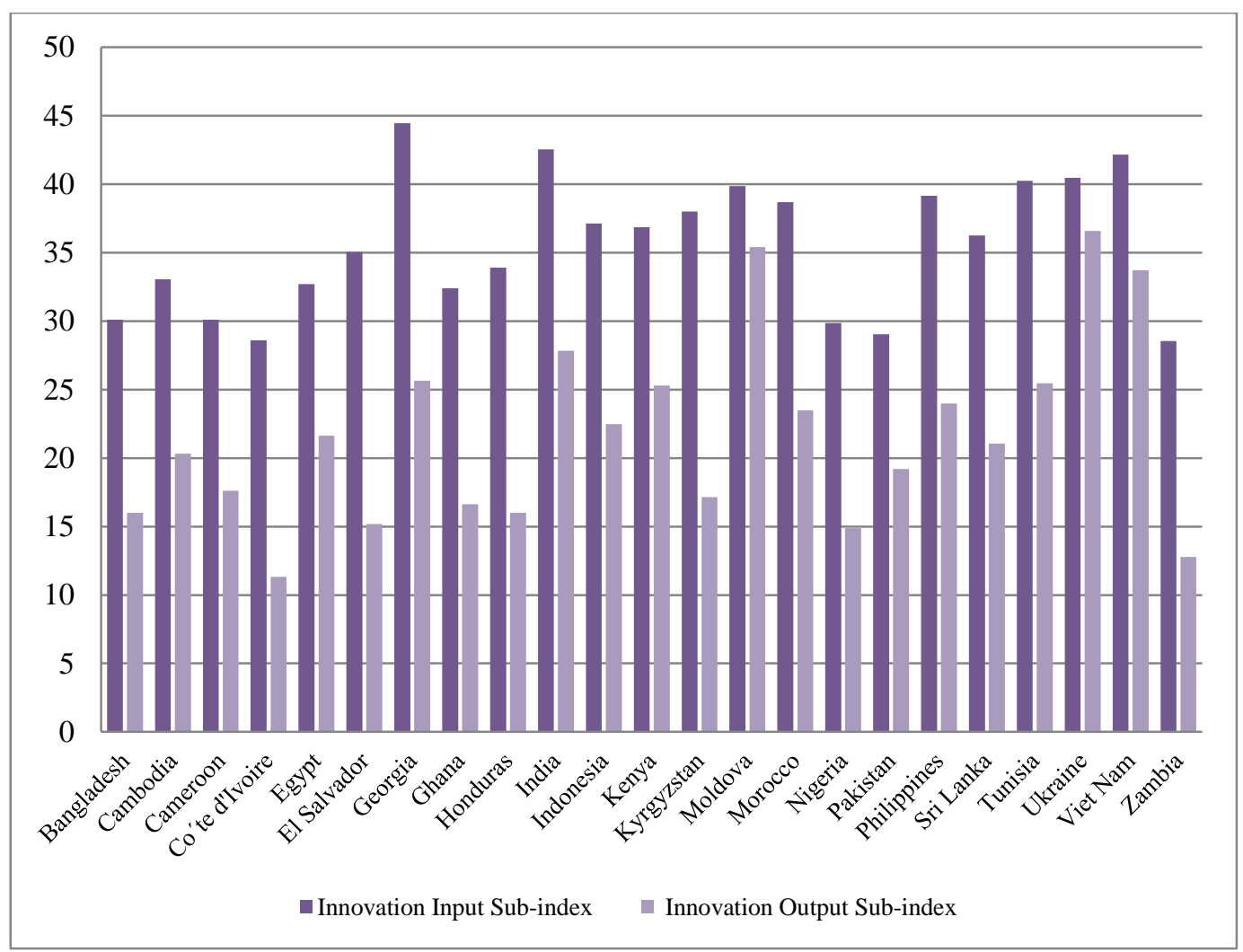

Source: Global Innovation Index, 2018.

Consequently, these values point out that the efficiency problem, in which the input values of countries are high, the output values are quite low. So, we can clearly express that those low middle-income countries are with a problem of inefficiency related to innovation performance.

Figure 2 shows the innovation input and output sub-indexes of upper middleincome countries. According to the figure, while the country with the highest performance in terms of innovation input sub-index is China (55.13); the country with the lowest performance is Guatemala (32.67). Malaysia (52.07), Russia (47.89), Bulgaria (47.61) and South Africa (45.36) can be considered as high performance countries. On the other hand, Algeria (33.67), Ecuador (35.48) and Armenia (36.40) also are the countries that have low performance according to the innovation inputs. In terms of innovation output sub-index, it can be seen that the countries with high performance are China (50.98), Malaysia (34.26), Bulgaria (37.68) and Turkey (32.19) respectively. 
Figure 2: Innovation Input and Output Sub-Indexes of Upper Middle-Income Countries

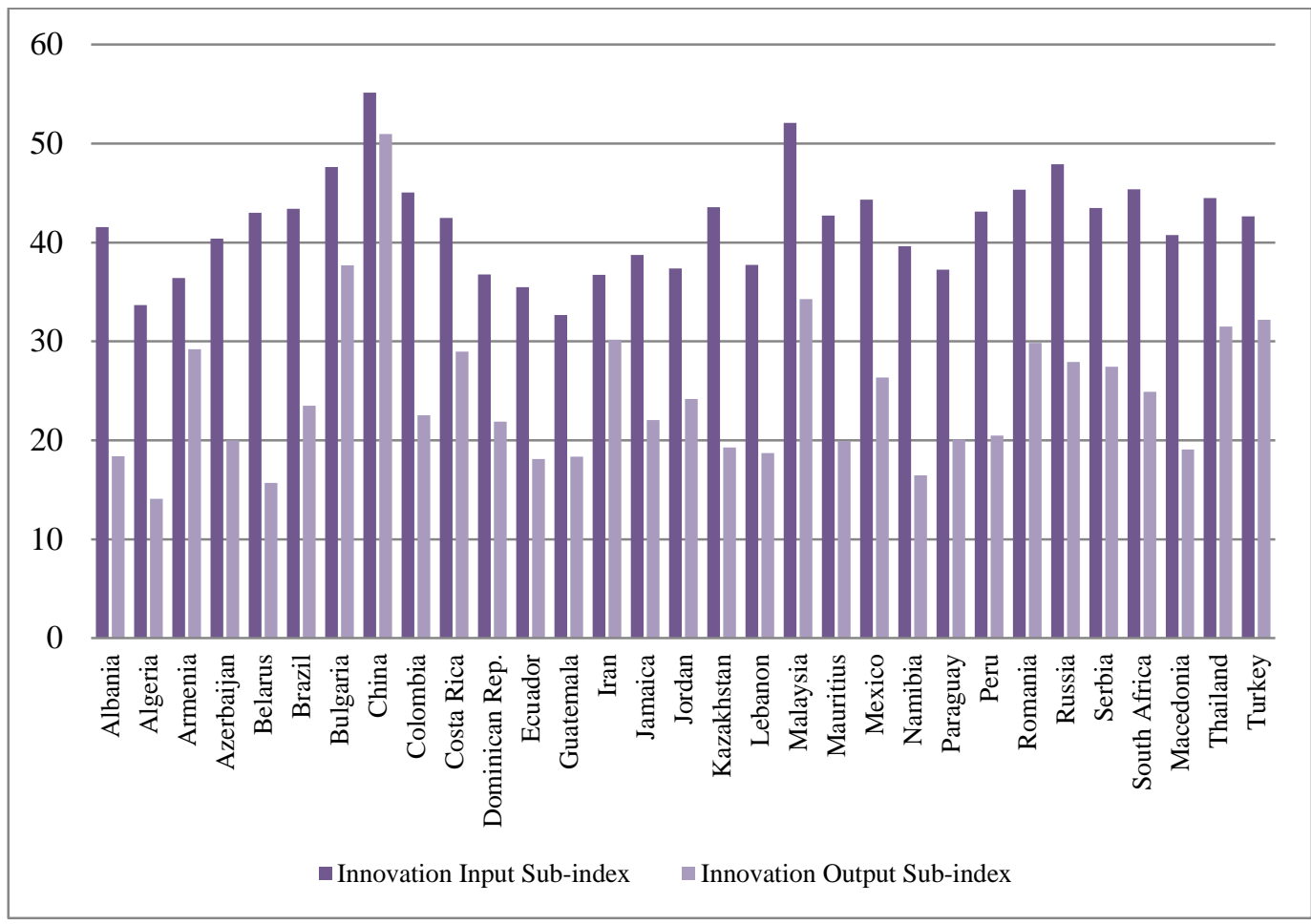

Source: Global Innovation Index, 2018.

The countries with the worst performance are Algeria (14.07), Belarus (15.70) and Namibia (16.44). As a result, in these countries, the innovation output values are below the innovation input values. It points out the existence of the efficiency problem for upper-middle-income countries.

In this study, two methods of analysis were used to determine the efficiency of the middle-income countries in their innovation performance. These methods cluster analysis and discriminant analysis. These analyses were applied separately to inputs and outputs of innovation. Cluster analysis is one of the multivariate statistical methods and it refers to the process of grouping similar objects into different groups. The main purpose of cluster analysis is to provide the researcher with suitable and useful information by classifying ungrouped data according to similarities (Atik and Ünlü, 2017: 1031). Observations in the cluster have similar characteristics but are dissimilar to the observations belonging to other clusters. Therefore, the purpose of cluster analysis is to maximize intra-cluster homogeneity and inter-cluster heterogeneity. While high heterogeneity means that observations in different clusters are far from each other, high homogeneity means that observations in the same cluster are close to each other (Nakip, 2006: 437-438). In cluster analysis, observations are grouped on the basis of similarities or dissimilarities. The distance between observations is calculated by the Euclidean 
distance. An Euclidean distance is a geometric distance between two observations. The formula of this distance is as below (Verma, 2013: 319):

$$
\text { deij }=\sqrt{\sum_{k=1}^{n}(X i k-X j k)^{2}}
$$

In the formulation, $X i k$ is the measurement of $i t h$ cases on $k t h$ variable; $X j k$ is the measurement of $j t h$ cases on $k t h$ variable and $n$ is the number of variables. If Euclidean distance is smaller, the cases are more similar. If Euclidean distance is greater, the cases are more dissimilar.

There are three types of cluster analyses: hierarchical, non-hierarchical and twostep cluster analyses (Sarstedt and Mooi, 2014: 275). If the researcher does not have preliminary information about the number of clusters, the hierarchical cluster analysis is preferred. Due to lack preliminary information on the number of clusters, the hierarchical cluster analysis is preferred in this study. In the hierarchical analysis, observations are grouped into a hierarchical structure. In other words, observations are grouped into a tree of clusters by using the distance matrix. In hierarchical cluster analysis, different methods are used to form the clusters. In this study, Ward method was applied. Ward (1963) introduced a method, in which the fusion of two clusters is based on the size of on error sum-of-squares criterion. In this method, clusters are formed if the variation within the two clusters is least. Therefore, this method is known as the minimum variance method (Everitt et al., 2011: 77). The error sum of squares is used to minimize the variance within the clusters (Ward, 1963: 237):

$$
E S S=\sum_{i=1}^{n} x_{i}^{2}-\frac{1}{n}\left(\sum_{i=1}^{n} x_{i}\right)^{2}
$$

where $x_{i}$ is the score of the $i$ th individual. In the first stage of the clustering process, the ESS is zero because each observation is a cluster.

Discriminant analysis is one of the multivariate statistical methods. It aims to estimate the relationship between categorical dependent variables and metric independent variables. The main aim of this analysis is to estimate group membership based on a linear combination of the predictive variables. The second aim is to identify the relationship between group membership and the variables used to predict group membership, which provides information about the relative importance of independent variables in predicting group membership. Also, this analysis tests whether cases are classified as predicted (Agresti, 1996: 590-591).

\section{Empirical Results}

This section contains the results of cluster and discriminant analyses. Firstly, findings obtained from cluster analysis using Ward's agglomeration hierarchical clustering method was given separately for inputs and outputs. Subsequently, the findings of the discriminant analysis were shown through tables. 
Table 4: Distribution of the countries by inputs

\begin{tabular}{ll}
\hline Clusters & Countries \\
\hline Cluster 1 & $\begin{array}{l}\text { Armenia, El Salvador, Honduras, Paraguay, Ecuador, Kyrgyzstan, Nigeria, } \\
\text { Pakistan, Co'te d'Ivoire, Cameroon }\end{array}$ \\
Cluster 2 & Ghana, Guatemala, Cambodia, Kenya \\
Cluster 3 & $\begin{array}{l}\text { Algeria, İran, Dominican Republic, Morocco, Egypt, Sri Lanka, Bangladesh, } \\
\text { Zambia, Indonesia, }\end{array}$ \\
Cluster 4 & India, South African, Malaysia, Philippines, Turkey, Brazil, Mexico, Thailand, \\
& Russian Federation \\
Cluster 5 & China \\
Cluster 6 & Albania, Azerbaijan, Georgia, Jamaica, Kazakhstan, Moldova, Macedonia \\
Cluster 7 & Belarus, Jordan, Lebanon, Tunisia, Ukraine \\
Cluster 8 & Bulgaria, Colombia, Peru, Romania, Serbia \\
Cluster 9 & Costa Rika, Mauritius, Namibia, Vietnam \\
\hline
\end{tabular}

Table 4 shows cluster members according to innovation inputs. The findings point out the existence of nine clusters. So, the middle-income countries are divided into nine groups in terms of innovation inputs. According to these results, Cluster 1 has two characteristics: first, it is the largest cluster in terms of the number of countries with 10 members. Second, it contains lower middle-income countries, with the exception of Paraguay and Ecuador. Similarly, all of the countries in cluster 2 are the countries included in low middle-income groups. Cluster 3 contains countries both lower and upper income countries. Cluster 4 includes upper middle-income countries, with the exception of India. The other hand, the countries in this group have a relatively high score in terms of innovation input sub-index (See, Global Innovation Index, 2018). Additionally, the three countries in this group are in the top 50 according to the innovation ranking. These countries are Malaysia, Russian Federation, and South Africa. Cluster 5 alone contains China. The main feature of this country is placed on the top among the middle-income countries. Cluster 6 and cluster 7 also have has a heterogeneous appearance. Cluster 8 similar to cluster 4 consists of the countries that have a high score in terms of innovation input subindex. Bulgaria, Romania, and Colombia in this cluster are in the top 50 according to the innovation ranking. The last cluster called cluster 9 is the smallest cluster in terms of the number of countries with four members. Briefly, middle-income countries have different levels of development in terms of innovation efforts and the results of cluster analysis are consistent with both income levels of the countries and innovation input sub-index scores calculated by the Global Innovation Index. 
Table 5: Classification Results-I

\begin{tabular}{|c|c|c|c|c|c|c|c|c|c|c|c|}
\hline & $\begin{array}{l}\text { Cluster } \\
\text { number }\end{array}$ & & & & dicted & Group M & embers & & & & Total \\
\hline & & 1 & 2 & 3 & 4 & 5 & 6 & 7 & 8 & 9 & \\
\hline \multirow{9}{*}{ Original Count } & 1 & 9 & 0 & 1 & 0 & 0 & 0 & 0 & 0 & 0 & 10 \\
\hline & 2 & 0 & 4 & 0 & 0 & 0 & 0 & 0 & 0 & 0 & 4 \\
\hline & 3 & 0 & 0 & 9 & 0 & 0 & 0 & 0 & 0 & 0 & 9 \\
\hline & 4 & 1 & 0 & 0 & 8 & 0 & 0 & 0 & 0 & 0 & 9 \\
\hline & 5 & 0 & 0 & 0 & 0 & 1 & 0 & 0 & 0 & 0 & 1 \\
\hline & 6 & 0 & 0 & 0 & 0 & 0 & 7 & 0 & 0 & 0 & 7 \\
\hline & 7 & 0 & 0 & 0 & 0 & 0 & 0 & 5 & 0 & 0 & 5 \\
\hline & 8 & 0 & 0 & 0 & 0 & 0 & 0 & 0 & 5 & 0 & 5 \\
\hline & 9 & 0 & 0 & 0 & 0 & 0 & 0 & 0 & 0 & 4 & 4 \\
\hline \multirow{9}{*}{$\%$} & 1 & 90,0 & ,0 & 10,0 & ,0 & , 0 & , 0 & , 0 & , 0 & , 0 & 100,0 \\
\hline & 2 &, 0 & 100,0 &, 0 &, 0 & 0 &, 0 & 0 & 0 & 0 & 100,0 \\
\hline & 3 &, 0 &, 0 & 100,0 &, 0 & , 0 &, 0 &, 0 & 0 &, 0 & 100,0 \\
\hline & 4 & 11,1 &, 0 &, 0 & 88,9 &, 0 &, 0 &, 0 &, 0 &, 0 & 100,0 \\
\hline & 5 &, 0 & ,0 & , 0 &, 0 & 100,0 &, 0 & , 0 & , & ,0 & 100,0 \\
\hline & 6 & , 0 & ,0 & , 0 & , 0 &, 0 & 100,0 & ,0 & ,0 & , 0 & 100,0 \\
\hline & 7 & ,0 & ,0 & ,0 & ,0 & ,0 &, 0 & 100,0 &, 0 &, 0 & 100,0 \\
\hline & 8 & , 0 & 0 & 0 &, 0 & 0 & 0 &, 0 & 100,0 & ,0 & 100,0 \\
\hline & 9 & ,0 & ,0 &, 0 &, 0 &, 0 &, 0 &, 0 &, 0 & 100,0 & 100,0 \\
\hline
\end{tabular}

Note: $96,3 \%$ of original grouped cases correctly classified.

The results of discriminant analysis related innovation inputs are given in Table 6 and Table 7. Table 6 illustrated classification results from the discriminant analysis. According to the table, cases are correctly classified to originally grouped $(\% 96,3)$. Therefore, cluster analysis is valid in terms of both numbers of clusters and cluster memberships.

Table 6: Tests of Equality of Group Means-I

\begin{tabular}{lccccc}
\hline Variables & Wilks' & & & & \\
Lambda & $\mathrm{F}$ & df1 & df2 & Sig. \\
\hline Political environment &, 487 & 5,919 & 8 & 45 &, 000 \\
Regulatory environment &, 535 & 4,888 & 8 & 45 &, 000 \\
Business environment &, 492 & 5,801 & 8 & 45 &, 000 \\
Education &, 574 & 4,178 & 8 & 45 &, 001 \\
Tertiary education &, 463 & 6,515 & 8 & 45 &, 000 \\
Research and development &, 169 & 27,733 & 8 & 45 &, 000 \\
Information and communication technologies &, 461 & 6,590 & 8 & 45 &, 000 \\
General infrastructure &, 423 & 7,688 & 8 & 45 &, 000 \\
Ecological sustainability &, 556 & 4,492 & 8 & 45 &, 000 \\
Credit &, 706 & 2,339 & 8 & 45 &, 034 \\
Investment &, 492 & 5,817 & 8 & 45 &, 000 \\
Trade, competition, \& market scale &, 387 & 8,893 & 8 & 45 &, 000 \\
Knowledge workers &, 337 & 11,078 & 8 & 45 &, 000 \\
Innovation linkages &, 492 & 5,808 & 8 & 45 &, 000 \\
Knowledge absorption &, 401 & 8,415 & 8 & 45 &, 000 \\
\hline
\end{tabular}

Table 6 shows the results tests of equality of group means. All variables are statistically significant at the 0.05 level $(\mathrm{p}<0.05)$. According to the Table, the most 
significant three variables that cause countries to be divided into different groups in terms of innovation inputs are research and development $(0,169)$; knowledge workers $(0,337)$ and trade, competition \& market scale $(0,387)$. The findings show that

the most important factors that differentiated countries in terms of innovation efforts are R\&D, employment in knowledge-intensive services and domestic market scale with competition conditions.

Table 7: Distribution of the countries by outputs

\begin{tabular}{ll}
\hline Clusters & Countries \\
\hline Cluster 1 & $\begin{array}{l}\text { Algeria, Zambia, Bangladesh, Pakistan, Co'te d'Ivoire, Colombia, South African, } \\
\text { Brazil, Kazakhstan, Kyrgyzstan, Azerbaijan, Egypt, Peru, Cameroon, Cambodia, } \\
\text { Jamaica, Morocco, Ecuador, Ghana, Guatemala }\end{array}$ \\
Cluster 2 & Namibia, Paraguay, Honduras, Nigeria, El Salvador \\
Cluster 3 & $\begin{array}{l}\text { Dominican Republic, Indonesia, Sri Lanka, Kenya, Tunisia, Albania, Mauritius, } \\
\text { Jordan, Lebanon }\end{array}$ \\
Cluster 4 & Moldova, Ukraine, Turkey, Iran \\
Cluster 5 & $\begin{array}{l}\text { Belarus, Macedonia, Bulgaria, Romania, Georgia, Serbia, Russian Federation, } \\
\text { Armenia }\end{array}$ \\
Cluster 6 & Malaysia, Costa Rika, Vietnam, Mexico, Thailand, India, Philippines \\
Cluster 7 & China \\
\hline
\end{tabular}

The analyses were repeated for innovation outputs. Firstly, it was performed cluster analysis by using six variables for 54 countries. According to the results of the analysis given in Table 7, the middle-income countries are classified under seven groups in terms of innovation outputs. These findings confirm that middle-income countries are not similar in terms of innovation outputs. The countries were grouped differently from the previous clustering analysis. In other words, the clustered countries according to the inputs took place in different clusters in the repeated analysis according to the outputs. However, it was reached findings similar to the results obtained from the previous analysis. For example, China has also formed a cluster by itself. On the other hand, Ghana, Cambodia, and Guatemala (Cluster 1) were included in the same cluster both analyses. Similarly, it is valid for Bulgaria, Romania and Serbia (Cluster 5); Dominican Republic, Indonesia and Sri Lanka (Cluster 3) with Honduras, Nigeria, El Salvador and Paraguay (Cluster 2). Considering the distribution of countries in terms of income groups, it can be seen that the countries are not classified according to income groups. So, all clusters are not homogenous, except Cluster 5 which includes upper middle-income countries. 
Table 8: Classification Results-II

\begin{tabular}{|c|c|c|c|c|c|c|c|c|c|c|}
\hline & & $\begin{array}{l}\text { Cluster } \\
\text { number }\end{array}$ & & & Predicte & oup N & bership & & & Total \\
\hline & & & 1 & 2 & 3 & 4 & 5 & 6 & 7 & \\
\hline & & 1 & 18 & 0 & 1 & 1 & 0 & 0 & 0 & 20 \\
\hline & & 2 & 0 & 5 & 0 & 0 & 0 & 0 & 0 & 5 \\
\hline & & 3 & 1 & 0 & 8 & 0 & 0 & 0 & 0 & 9 \\
\hline Original & Count & 4 & 0 & 0 & 1 & 3 & 0 & 0 & 0 & 4 \\
\hline & & 5 & 0 & 0 & 0 & 0 & 8 & 0 & 0 & 8 \\
\hline & & 6 & 0 & 0 & 0 & 1 & 0 & 6 & 0 & 7 \\
\hline & & 7 & 0 & 0 & 0 & 0 & 0 & 0 & 1 & 1 \\
\hline & & 1 & 90,0 & ,0 & 5,0 & 5,0 & ,0 & , 0 & ,0 & 100,0 \\
\hline & & 2 &, 0 & 100,0 &, 0 &, 0 &, 0 & ,0 & , 0 & 100,0 \\
\hline & & 3 & 11,1 &, 0 & 88,9 & , 0 & 0 & , 0 & ,0 & 100,0 \\
\hline & $\%$ & 4 &, 0 & ,0 & 25,0 & 75,0 & ,0 & , 0 & ,0 & 100,0 \\
\hline & & 5 &, 0 & ,0 &, 0 &, 0 & 100,0 &, 0 & ,0 & 100,0 \\
\hline & & 6 & , 0 & ,0 & , 0 & 14,3 &, 0 & 85,7 &, 0 & 100,0 \\
\hline & & 7 & , 0 & ,0 &, 0 &, 0 &, 0 &, 0 & 100,0 & 100,0 \\
\hline
\end{tabular}

Note: $90,7 \%$ of original grouped cases correctly classified.

Table 8 shows classification results from the discriminant analysis. According to the table, cases are correctly classified to originally grouped $(\% 90,7)$. So, cluster analysis is valid in terms of both numbers of clusters and cluster memberships.

Table 9: Tests of Equality of Group Means-II

\begin{tabular}{lccccc}
\hline Variables & Wilks' Lambda & F & df1 & df2 & Sig. \\
\hline Knowledge creation &, 342 & 15,044 & 6 & 47 &, 000 \\
Knowledge impact &, 370 & 13,347 & 6 & 47 &, 000 \\
Knowledge diffusion &, 384 & 12,565 & 6 & 47 &, 000 \\
Intangible assets &, 604 & 5,142 & 6 & 47 &, 000 \\
Creative goods and services &, 437 & 10,100 & 6 & 47 &, 000 \\
Online creativity &, 341 & 15,150 & 6 & 47 &, 000 \\
\hline
\end{tabular}

Table 9 shows the results tests of equality of group means. All variables are statistically significant at the 0.05 level $(\mathrm{p}<0.05)$. The most significant variables that cause countries to be divided into different groups according to innovation outputs are online creativity $(0.341)$; knowledge creation $(0,342)$; knowledge impact $(0,370)$ and knowledge diffusion $(0,384)$. The most important factors determining the performances in terms of the innovation outputs are elements affecting the use of the ICTs and contributing to the creation of knowledge (for example, number of the patents, scientific and technical publications and citations, etc.). In addition to this, the factors like foreign direct investments net inflows, hightechnology exports, intellectual property, ICT service exports, and trademark application are important innovation performance indicators of the middle-income countries. 


\section{Conclusion}

In the paper, we tried to determine the differences in the efficiency of innovation performance in middle-income countries by using statistical methods. The findings showed as follows: i) according to cluster analysis, the results related to innovation inputs and outputs are consistent with both income levels of the countries and innovation input sub-index and outputs sub-index scores. ii) Although clusters exhibit relatively homogeneity, according to innovation inputs and outputs, the middle-income countries display a heterogeneous appearance which means there is an inconsistency between eco-innovation inputs of the countries and their outputs and points out the inefficiency problem in terms of innovation performance (Kula and Ünlü, 2019). So, the innovation efforts of the countries are different and naturally, this case leads to that the innovation performance also varies.

Additionally, the discriminant analysis was used to identify factors that lead to differences in efficiency. The findings are as follows: i) the $\mathrm{R} \& \mathrm{D}$ are the most important factor determining innovation inputs related to the performance in the middle-income countries. Second is employment in knowledge-intensive services. ii) use of the ICTs is the most important factor determining the performances in terms of the innovation outputs. The second factor is also the creation of knowledge.

The fact that middle-income countries can reach the high income countries group depends on the transition from the source-based growth model to the innovationbased growth model. Therefore, the fundamental policy targets of these countries should focus on innovation and technology. In countries with similar levels of development, innovation performance is expected to be similar. So, the innovation performance is high in high-income countries and mostly the countries are similar to each other in this aspect. However, in this respect, middle-income countries have different characteristics than high income countries. Because there are significant differences between innovation inputs and outputs in these countries. Hence, proposed single or common policy for all middle-income countries may not be appropriate.

\section{References}

Agresti, A. (1996). An Introduction to Categorical Data Analysis. USA: John Wiley and Sons Ltd.

Altınel, F. (2012). An Empirical Study on Fuzzy C-Means Clustering for Turkish Banking System, The Graduate School of Social Sciences of Middle East Technical University, Ankara.

Arı, E. ve Yıldız, A. (2018). OECD Ülkelerinin Göç İstatistikleri Bakımından Bulanık Kümeleme Analizi ile İncelenmesi, Pamukkale Üniversitesi Sosyal Bilimler Enstitüsü Dergisi, 33, 17-28. 
Artis, M.J. and Zhang, W. (2002). Membership of EMU: A Fuzzy Clustering Analysis of Alternative Criteria, Journal of Economic Integration, 17(1), 5479.

Atik, H. and Ünlü, F. (2017). Science Performance of Turkey in 21St Century: A Multivariate Statistical Comparison with the OECD Countries, In: Researches on Science and Art in 21st Century Turkey, Arapgirlioğlu H., Atik A., Elliot R. L., Turgeon E. Eds., Ankara: Gece Publishing, 1030-1038.

Baculakova, K. and Gress, M. (2015). Cluster Analysis of Creative Industries in the EU, Economic Annals-XXI, 9-10, 15-18.

Barasa, L., Vermeulen, P., Knoben, J., Kinyanjui, B. and Kimuyu, P. (2019). Innovation Inputs and Efficiency: Manufacturing Firms in Sub-Saharan Africa, European Journal of Innovation Management, 22 (1), 59-83.

Bivand, R.S., Wilk, J. and Kossowski, T. (2017). Spatial Association of Population Pyramids across Europe: The Application of Symbolic Data, Cluster Analysis and Join-count Tests, Spatial Statistics, 21, 339-361.

Broekel, T., Rogge, N. and Brenner, T. (2013). The Innovation Efficiency of German Regions-a Shared-input DEA Approach, Working Papers on Innovation and Space Philipps-Universität Marburg.

Cai, Y. (2011). Factors Affecting the Efficiency of the BRICSs' National Innovation Systems: A Comparative Study based on DEA and Panel Data Analysis, Economics Discussion Paper No. 2011-52.

Chou, J. and Gao, F. (2013). Innovation Efficiency, Global Diversification, and Firm Value, http://cafd.cufe.edu.cn/docs/201305/20130527101741442337.pdf, (Access: 15.01.2019)

Christensen, I. A., Davidian, K., Kaiser, D. and Foust, F. (2010). Applying Disruptive Innovation Theory in Emerging Markets for Crew On-Orbit Transportation, https://swfound.org/media/199710/ic_iac_sep2010.pdf (Access: 15.11.2015)

Çiçek, H. ve Onat, O. K. (2012), İnovasyon Odaklı Faaliyetlerin Firma Performansına Etkisinin Veri Zarflama Analizi ile Belirlenmesi; İMKB Üzerine Bir Araştırma, Mehmet Akif Ersoy Üniversitesi Sosyal Bilimler Enstitüsü Dergisi, 4 (7), 46-53.

Egawa, A. (2013). Will Income Inequality Cause a Middle-income Trap in Asia?, Bruegel Working Paper, No: 2013/06.

Erkekoğlu, H. ve Arıç, H.K. (2013). APEC Ülkeleri ve Türki-ye'nin Bilgi Toplumu Kriterleri Açısından İstatistiksel Analizi ve Bazı Tespitler, Bilgi Ekonomisi ve Yönetimi Dergisi, 8 (1), 103-114. 
Ersöz, F. (2009). Avrupa İnovasyon Göstergeleri (EIS) Işı̆̆ında Türkiye'nin Konumu, ITÜ Dergisi/b Sosyal Bilimler, 6 (1), 3-16.

Everitt, B.S., Landau, S., Leese, M. and Sathal, D. (2011). Cluster Analysis, Fifth Edition, UK: John Wiley \& Sons, Ltd.

Foreman-Peck, J. (2012). Effectiveness and Efficiency of SME Innovation Policy, Cardiff Economics Working Papers, No. E2012/4, Cardiff University, Cardiff Business School, Cardiff.

Gill, I. and Kharas, H. (2007). An East Asian Renaissance: Ideas for Economic Growth, Washington: World Bank Publications.

Hajek, P. and Henriques, R. (2017). Modelling Innovation Performance of European Regions using Multi-output Neural Networks, PLOS One, 12 (10), 121.

Henderson, R. M. and Clark, K.B. (1990). Architectural Innovation: The Reconfiguration Of Existing, Administrative Science Quarterly, 35 (1), 9-30.

Herimalala, R. and Gausesns, O. (2012). X-Efficiency of Innovation Processes: Concept and Evaluation based on Data Envelopment Analysis, MPRA Paper No. 42872.

Jankowska, A., Nagengast, A. J. and Perea, J. R. (2012). The Middle-income Trap: Comparing Asian and Latin American Experiences, OECD Development Centre Policy Insights, No: 96.

Kula, F. and Ünlü, F. (2019). Ecological Innovation Efforts and Performances: an Empirical Analysis, In: Energy and Environmental Strategies in the Era of Globalization, Shahbaz, M.; Balsalobre, D. Eds. Chapter 9, Switzerland: Springer, 221-250.

Nakip, M. (2006). Pazarlama Araştırmaları Teknikler ve (SPSS Destekli) Uygulamalar. Genişletilmiş İkinci Baskı, Ankara: Seçkin Yayıncılık.

Nasierowski, W. and Arcelus, F. J. (2012). About Efficiency of Innovations: What Can Be Learned From The Innovation Union Scoreboard Index, 8th International Strategic Management Conference Procedia - Social and Behavioral Sciences, 58, 792-801.

OECD-Eurostat (2005). Oslo Kllavuzu: Yenilik Verilerinin Toplanması ve Yorumlanması İçin İlkeler, Üçüncü Baskı, Ankara: TÜBİTAK Yayınları.

Özbek, H. ve Atik, A. (2013). İnovasyon Göstergeleri Bakımından Türkiye'nin Avrupa Birliği Ülkeleri Arasındaki Yeri: İstatistiksel Bir Analiz, Erciyes Üniversitesi İktisadi ve İdari Bilimler Fakültesi Dergisi, 42, 193-210.

Popescu, M.E.; Cristescu, A. and Stanila, A. (2016). Net Earnings Trends in the EU Countries, Theoretical and Applied Economics, XXIII, No. 3(608), 351-360. 
Porter, M. E. (1991). The Competitive Advantage of Nations, New York: MacMillan Press.

Roszko-Wojtowicz, E. and Bialek, J. (2017). Evaluation of the EU Countries' Innovative Potential-Multivariate Approach, Statistics in Transition New Series, 18 (1), 167-180.

Saatçioğlu, C. ve Bildirici, Ü. (2017). İnovasyon Göstergeleri Bakımından Türkiye'nin OECD Ülkeleri Arasındaki Yeri: Ekonometrik Bir Uygulama, İsletme ve İktisat Çalışmaları Dergisi, 5 (4), 44-56.

Sarstedt, M. and Mooi, E. (2014). Cluster Analysis. In: A Concise Guide to Market Research. Springer Texts in Business and Economics, Sarstedt, M.; Mooi, E. Eds.; Springer: Berlin, 273-324.

Schmidt, T. and Rammer, C. (2007). Non-technological and Technological Innovation: Strange Bedfellows?, Centre for European Economic Research Discussion Paper No. 07-052.

Schumpeter, J. A. (1934). The Theory of Economic Development, New Jersey: Transaction Publishers.

Strozek, P. (2012). Comparative Analysis of the Level of Knowledge-based Part of Economies in European Union Countries with KAM Methodology, Comparative Economic Research, 15 (4), 249-263.

The World Bank (2019). Country Classifications, https://datahelpdesk.worldbank.org/knowledgebase/articles/906519-worldbank-country-and-lending-groups (Access: 06.04.2019)

Trott, P. (2005). Innovation Management and New Product Development (Fifth Edition), UK: Pearson Education Limited.

Verma, J.P. (2013). Data Analysis in Management with SPSS Software. India: Springer.

Ward, J.H. (1963). Hierarchical Grouping to Optimize an Objective Function, Journal of the American Statistical Association, 58, 236-244.

WIPO (2018). The Global Innovation Index 2018, Geneva, Switzerland.

Yeldan, E. (2012). Türkiye Orta Gelir Tuzağına Yaklaşırken, İktisat ve Toplum Dergisi, 21-22, 26-30.

Yeloğlu, H.O. (2009). Bilgi Ekonomisi Değişkenlerine Yönelik İlk İzlenimler: Türkiye OECD Ülkeleri Karşılaştırmaları (1995-1999), Bilgi Dünyası, 10 (2), 245-260.

Yılmaz, Y. K.; Yılmaz, M.; Yiğitbaşı, M.E. ve Çoban, O. (2016). İnovasyon İndeksi Yardımıyla Türkiye'de İllerin Rekabetçilik Analizi: Düzey-III Örneği, Sosyoekonomi, 24(30), 71-90. 